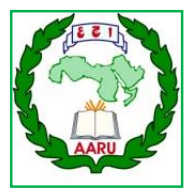

Arab Univ. J. Agric. Sci., Ain Shams Univ., Cairo, Egypt

28(1), 265-273, 2020

Website: http://ajs.journals.ekb.eq

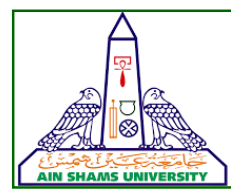

\title{
EFFECT OF SEAWEED EXTRACT AND BIOFERTILIZER ON ORGANIC PRODUCTION OF COMMON BEAN SEEDS (Phaseolus vulgaris L.)
}

Amin* M.S., El-Shinawy M.Z., Abdullah M.M.F. and Abd El-Gawad H.G.

Horticulture Dept., Fac. of Agric., Ain Shams Univ., P.O. Box 68, Hadayek Shoubra 11241, Cairo, Egypt

*Corresponding author: Shahat894@yahoo.com

Received 9 April, 2020

Accepted 7 May, 2020

\section{ABSTRACT}

At the Experimental Farm, Agriculture Faculty, University of Ain Shams, Qaliobia Governorate, Egypt, in order to investigate the influence of biofertilizer ( Bio. ); Rhizobium ( R ), mycorrhiza ( MF ), R + MF and control, seaweed extract (SWE) concentration (zero, one, two and four gram per liter) and their interactions on vegetative growth, productivity and quality of seed common bean cv. Nebraska. Before planting, the seeds were soaked in MF (glomus sp.) and sown on the first of March 2016 and 2017 seasons respectively. The experimental plot area was seven $\mathrm{m}^{2}$ (four rows). The length of each row was $2.5 \mathrm{~m}$ and width of $0.7 \mathrm{~m}$. The plant's distance was seven $\mathrm{cm}$ on one side, and an alley (one width $\mathrm{m}$ ) was left as a border between the treatments. After two weeks of planting, young plant were inoculated with $\mathrm{R}$ phaseolus after the first irrigation. Plants were sprayed three times of SWE (30, 45 and 60 days) after sowing. A split plot design with four replicates was used; where the main plots are Bio treatments and the subplots are SWE treatments. The obtained results clearly indicated that different applied treatments increased measured growth characteristics (No. leaves/ plant, leaf area and total chlorophyll (SPDS)), the yield and components of yield (No. pods/plant, seed yield/plant and seed yield) and chemical constituents (total protein, carbohydrates, nitrogen and phosphorus) in seed after harvest. As well as, the best results were obtained by interactions between SWE (two and four gram per liter) and Bio. ( $+M F)$ treatments in the two assigned seasons So adding combination between Bio. ( $R+M F)$ and SWE (two or four g) to improve vegetative growth, productivity and quality of common bean seed could be recommended under organic system ( conversion to organic agriculture).

Keywords: Seaweed, Seeds production, Common bean, Carbohydrates Protein and Biofertilizer (Rhizobium and Mycorrhizal).

\section{INTRODUCTION}

Common bean are one of the most important fabacea vegetable which being widely consumed in many countries and its predominant export crop, as well as it provable high protein content (Zewail, 2014).

Seaweed extract (SWE) is a natural organic fertilizers containing highly effective nutritious and promotes faster seeds germination and increase yield and resistant ability of many crops (Zewail, 2014). Unlike, chemical fertilizers, extracts derived from SWE are biodegradable, nontoxic, nonpolluting and non-hazardous to plants. Exogenous application of SWE has already been shown to enhance plant growth, yield and its quality, as reported by Abdel Mawgoud et al (2010) on celeriac plant and Abou El-Yazied et al (2012) on Snap Bean.

Mycorrhizal fungi (MF) colonize most of agricultural crops and also play an important role in Phosphorus supply to plants in Phosphorus deficient farming systems. The importance of MF in Phosphorus supply may be comparable to that of root hairs.Their hyphae can extend further from roots than the root hairs, which resulted in a higher soil volume that a colonized root can explore. Furthermore, MF can protect plants against toxic elements $(\mathrm{Zn}, \mathrm{Cd}$, and $\mathrm{Mn}$ ) by accumulation of these in their 
hyphae and may enhance plants tolerance against pathogen by competing with pathogenic microorganisms (Turk et al 2006). For Faba bean root colonization by indigenous MF increased vegetative growth and seed yield in addition to improving nodulation (Mathur and Vyas, 2000).

Dall'Agnol et al (2014) observed considerable increase in percentage of nodulated plants and protein in seed under field conditions due to seed inoculation in soils apparently free of Rhizobium (R). However, studies on organic manuring indicated that haricot bean showed positive response to such fertilizer. Moreover, biofertilization is currently gaining increasing importance as an alternative strategy to chemical fertilization particularly in low input agricultural systems.

Therefore, the present research aims to study the effect of SWE and Bio inoculation on growth and seed yield of common bean conversion to organic system (conversion to organic agriculture).

\section{MATERIALS AND METHODS}

At the experimental farm, Agriculture Faculty, University of Ain Shams, Qaliobia governorate, Egypt, In order to investigate the effect of SWE and Bio on vegetative growth, productivity and quality of seed common bean (Phaseolus vulgaris L.).

Seeds of common bean cv. Nebraska were sown on the first of March 2016 and 2017 seasons respectively. Rabbit manure and Chicken manure were added at the recommended dose i.e., $60 \mathrm{~kg}$ $\mathrm{N} / \mathrm{fed}$. All cultural practices for the cultivation of common bean plants as recommended in the organic production area (conversion to organic agriculture) for the production of dry bean seeds have been implemented. Cultural management, disease and pest control programs were followed according to the recommendations of the Egyptian Ministry of agriculture. Harvesting was carried out for each sowing date when seeds were matured (start yellowing and dried of leaves.

SWE (powder form) were produced by U.A.D. Co. Egypt (Table 1). SWE was used at four concentrations, i.e., zero (control, sprayed with tap water) dose of one, two and four $\mathrm{g} / \mathrm{L}$, applied after 30 , 45and 60 days from sowing days as a foliar application.

Table 1. Chemical and biochemical analyses of SWE, according to UAD ${ }^{\circledR}$ Company

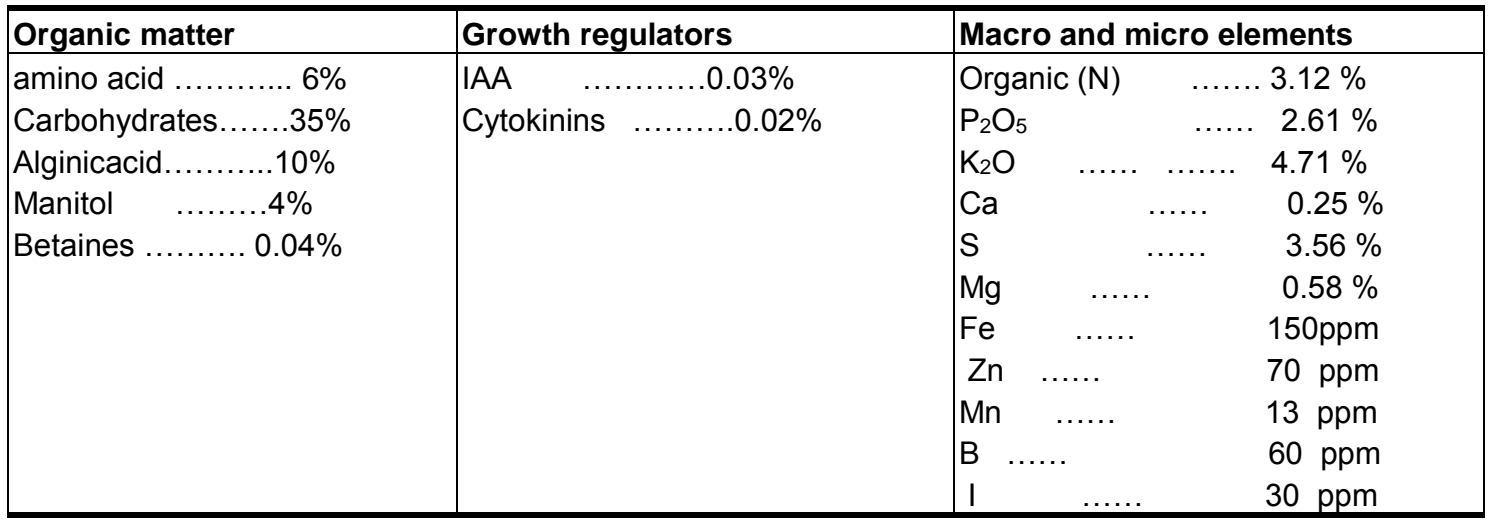

Rhizobium phaseolus and Mycorrhiza( glomus sp.) were bought from the Marsam Faculty of Agriculture, Ain Shams University.

\section{Studied characteristics}

\section{Vegetative characteristics}

Sample of three plants from each plot were randomly taken after forty five days from sowing for measured. The following characteristics: - Number of leaves / plant, total chlorophyll reading (SPAD), total leaf area $\left(\mathrm{cm}^{2}\right)$ / plant were using the disk method according:

Leaf area $\left(\mathrm{cm}^{2}\right)=\frac{\begin{array}{c}\text { Disk area } \times \text { Number of Disks } \times \\ \text { Leaf (fresh weight) }\end{array}}{\text { Disk (fresh weight) }}$




\section{Chemical analyses}

1. Percentage of seed total protein: total $\mathrm{N} \%$ was determined colorimetrically as shown in seed samples, the fourth expanded upper seed of three plants in middle row per plot (Jackson, 1973) and a factor of 6.25 was used for conversion of total $\mathrm{N}$ to protein percentage.

2. Percentage of seed total carbohydrate: It was measured in the dry matter of seed of three plants in middle row per plot; samples were measured calorimetrically according to A.O.A.C.2005.

3. Total phosphorus in seeds: It was determined as reported (mg/ $100 \mathrm{mg} \mathrm{DW})$.

\section{Yield and yield components}

Sample of ten plants from each plot were harvested to measuring the following character: No. pods/plant, seed yield /plant and expected seed (yield $/$ Fadden $)=$ seed yield/plant $X$ number of plants/Fadden.

\section{Statistical analysis}

The two seasons data were arranged and statistically analyzed using the $\mathrm{M}$ static program. The comparison between the different treatment methods has been determined, as previously explained by Snedecor and Cochran (1982).

\section{RESULTS AND DISCUSSION}

\section{Vegetative characteristics}

The data presented in Table (2) show the influence of SWE, Bio and their interaction during 2016 and 2017 seasons on No. of leaves /plant, leaf area and chlorophyll reading (SPAD). In general, the vegetative growth of common bean responded positively to Bio treatments. Inoculated seedling with arbuscular MF plus R gave the highest significant values of vegetative growth in the both seasons. These results in harmony with Salih et al (2015), AbdelFattah et al (2011) and Tajini et al (2012). In this respect, found that growth parameters of cantaloupe and cucumber plants treated with MF were generally increased by $10-25 \%$ with $85 \%$ water regime than untreated (control) plants grown with
$100 \%$ water regime. It has been shown that colonizing MF in wheat under water stress conditions has a beneficial effect on the state of the water, enhances the absorption of plant water, reduces the reduced water content of leaves and light pigments, and increases the overall gross weight. Shokri and Maadi (2009) It was reported that colonization of MF increased the total dry weight (TDW) of plants pollinated with MF by 5.29 times more than control plants. Most of the phosphorous in insoluble compounds was not available for cultivation. Root bacteria that promote plant growth (PGPR) are able to emerge from a beneficial effect on plant growth, nitrogen fixation and melting $P$.

Respecting the foliar application of SWE, the obtained data showed that the foliar application of SWE at two or four $\mathrm{g} / \mathrm{L}$ increased No. of leaves /plan, leaf area and chlorophyll reading (SPAD) as compared with the other studied seaweed extract treatments. Almost had similar values by Abbas (2013), Abo-Seder et al (2016), Abou El-Yazied et al (2012), Boghdady (2016) and Zewail (2014).

The growth enhancing potential of SWE might be attributed to the presence of growth regulators and macro elements. SWE have been known to promote the growth of vegetables, fruits, and other crops as they have been reported to contain growth regulators such as loxin (IAA and IBA), gibberelin, cytokines, betenes and macronutrients. The results obtained by Sridhar and Rengasamy (2010) confirm our results, Sargassum wightii brown peanuts treated with liquid seaweed fertilizers showed an increase in physical parameters such as imaging height, gross fresh and dry weight, number of branches and leaf area of the third young leaf The trees. He attributed this to the fact that SWE contains a maximum amount of $\mathrm{K}$ compared to other total nutrients $N$ and $P$. These results may be attributed to the beneficial effect of SWE containing natural nutrients, plant growth hormones (oxins, cytokines, and gibberellins) as well as stimulants Other plant vitals; for example amino acids, vitamins that can maintain photosynthesis rates, improve plant resistance, delay plant aging and cell division. Concerning the interactions, the studied combination between Bio and SWE treatments indicated that inoculated seedling with arbuscular MF plus $R$ with foliar application of SWE at two $\mathrm{g} / \mathrm{L}$ gave the highest significant No. of leaves /plant, leaf area and chlorophyll reading compared to the other interaction treatments. 
Table 2. Effect of Bio, SWE and their interaction on vegetative characteristics of common bean (combined of 2016 and 2017 seasons)

\begin{tabular}{|c|c|c|c|c|}
\hline \multicolumn{2}{|c|}{ Treatment } & \multicolumn{3}{|c|}{ Characters } \\
\hline Bio & $\begin{array}{l}\text { SWE } \\
\text { g/L }\end{array}$ & $\begin{array}{c}\text { Chlorophyll } \\
\text { reading (SPAD) }\end{array}$ & $\begin{array}{l}\text { No. of Leaves } \\
\text { /plant }\end{array}$ & Leaf area $\left(\mathrm{cm}^{2}\right)$ \\
\hline $\begin{array}{l}\text { Control } \\
\text { R } \\
\text { MF } \\
\text { Combination }\end{array}$ & $\begin{array}{c}\text { Mean } \\
\text { Bio }\end{array}$ & $\begin{array}{l}44.65 \mathrm{D}^{\prime} \\
45.59 \mathrm{C}^{\prime} \\
46.90 \mathrm{~B}^{\prime} \\
48.57 \mathrm{~A}^{\prime}\end{array}$ & $\begin{array}{l}17.39 \mathrm{D}^{\prime} \\
19.66 \mathrm{C}^{\prime} \\
20.79 \mathrm{~B}^{\prime} \\
21.76 \mathrm{~A}^{\prime}\end{array}$ & $\begin{array}{l}219.28 D^{\prime} \\
246.86 B^{\prime} \\
229.45 C^{\prime} \\
269.98 A^{\prime}\end{array}$ \\
\hline $\begin{array}{l}\text { Mean } \\
\text { SWE }\end{array}$ & $\begin{array}{l}0 \\
1 \\
2 \\
4\end{array}$ & $\begin{array}{l}44.51 \mathrm{C} \\
45.55 \mathrm{~B} \\
47.97 \mathrm{~A} \\
47.68 \mathrm{~A} \\
\end{array}$ & $\begin{array}{l}17.70 \mathrm{C} \\
18.44 \mathrm{~B} \\
21.72 \mathrm{~A} \\
21.74 \mathrm{~A}\end{array}$ & $\begin{array}{l}212.36 \mathrm{C} \\
230.30 \mathrm{~B} \\
260.17 \mathrm{~A} \\
262.75 \mathrm{~A}\end{array}$ \\
\hline $\begin{array}{c}\text { R } \\
\text { MF } \\
\\
\begin{array}{c}\text { Combination } \\
\text { (Bio) }\end{array}\end{array}$ & $\begin{array}{l}0 \\
1 \\
2 \\
4 \\
0 \\
1 \\
2 \\
4 \\
0 \\
1 \\
2 \\
4 \\
0 \\
1 \\
2 \\
4\end{array}$ & $\begin{array}{c}42.06 \mathrm{~g} \\
43.90 \mathrm{f} \\
46.05 \mathrm{ce} \\
46.58 \mathrm{be} \\
43.70 \mathrm{f} \\
45.10 \mathrm{ef} \\
47.00 \mathrm{bd} \\
46.54 \mathrm{be} \\
45.49 \mathrm{de} \\
46.04 \mathrm{ce} \\
48.09 \mathrm{~b} \\
47.99 \mathrm{~b} \\
46.77 \mathrm{bd} \\
47.16 \mathrm{bc} \\
50.75 \mathrm{a} \\
49.60 \mathrm{a}\end{array}$ & $\begin{array}{c}15.63 \mathrm{~h} \\
16.58 \mathrm{gh} \\
18.50 \mathrm{ef} \\
18.83 \mathrm{ef} \\
17.71 \mathrm{fg} \\
18.58 \mathrm{ef} \\
21.00 \mathrm{~d} \\
21.35 \mathrm{~cd} \\
18.46 \mathrm{ef} \\
19.25 \mathrm{e} \\
22.96 \mathrm{~b} \\
22.50 \mathrm{bc} \\
19.00 \mathrm{ef} \\
19.33 \mathrm{e} \\
24.42 \mathrm{a} \\
24.29 \mathrm{a}\end{array}$ & $\begin{array}{c}196.29 \mathrm{j} \\
210.11 \mathrm{hi} \\
234.03 \mathrm{fg} \\
236.69 \mathrm{fg} \\
216.79 \mathrm{~h} \\
254.32 \mathrm{de} \\
249.77 \mathrm{e} \\
266.57 \mathrm{c} \\
206.94 \mathrm{hj} \\
202.93 \mathrm{ij} \\
243.36 \mathrm{ef} \\
264.58 \mathrm{~cd} \\
229.42 \mathrm{~g} \\
253.85 \mathrm{de} \\
313.51 \mathrm{a} \\
283.14 \mathrm{~b}\end{array}$ \\
\hline L.S.Do.05 & $\begin{array}{l}\text { Bio. } \\
\text { SWE } \\
\text { Bio* SWE }\end{array}$ & $\begin{array}{l}0.493 \\
0.501 \\
1.416\end{array}$ & $\begin{array}{c}0.6876 \\
0.4522 \\
1.279\end{array}$ & $\begin{array}{c}2.5328 \\
3.8028 \\
10.76\end{array}$ \\
\hline
\end{tabular}

Means having the same letters (s) are not significantly different. Duncan's multiple range test at $(\mathrm{P} \leq 0.05)$.

\section{Fruit characteristics}

The data presented in Table (3) show the influence of Bio, SWE and their interaction during 2016 and 2017 seasons on No. of pods /plant, seed yield (Kg/Fed) and seed yield per plant (g). In general, fruit characteristics of common bean responded positively to Bio (R and MF) No. of pods /plant, seed yield (Kg/Fed) and seed yield per plant $(\mathrm{g})$ as compared with the other studied Bio treatments. These results in harmony with, Abdel-Fattah (2011), Salih et al (2015) and Gamal et al (2016).

Respecting the foliar application of SWE, the obtained data showed that the foliar application of SWE (fourg) increased no. of pods /plant, seed yield (Kg/Fed) and seed yield per plant ( $\mathrm{g}$ ) as compared with the other studied seaweed treatments, almost had similar values by Abou El-Yazied et al (2012), Zodape et al (2010), Ramya et al (2010) and Boghdady (2016).

Concerning the interactions, the studied combination between biofertilizer and SWE indicated that plants Bio (R + MF) and seaweed $(4 \mathrm{~g})$ showed No. of pods /plant, seed yield (Kg/Fed) and seed yield per plant $(\mathrm{g})$ than the other combination treatments.

\section{Chemical constituents}

The data presented in Table (4) show the influence of Bio, SWE and their interaction during 2016 and 2017 seasons on total protein (\%), total carbohydrates (g/100g d.wt), P (\%) and N(\%). In general, chemical constituents of common bean seeds responded positively to Bio (R and MF) increased total 
Table 3. Effect of Bio, SWE and their interaction on fruit characteristics of common bean, (combined of 2016 and 2017 seasons)

\begin{tabular}{|c|c|c|c|c|}
\hline \multicolumn{2}{|c|}{ Treatment } & \multicolumn{3}{|c|}{ Characters } \\
\hline Bio & $\begin{array}{l}\text { SWE } \\
(g / L)\end{array}$ & $\begin{array}{l}\text { No. of pods } \\
\text { /plant }\end{array}$ & $\begin{array}{l}\text { Seed yield per } \\
\text { plant }(\mathrm{g})\end{array}$ & $\begin{array}{c}\text { Seed yield } \\
(\mathrm{Kg} / \mathrm{Fed})\end{array}$ \\
\hline $\begin{array}{l}\text { Control } \\
\text { R } \\
\text { MF } \\
\text { Combination }\end{array}$ & $\begin{array}{c}\text { Mean } \\
\text { Bio }\end{array}$ & $\begin{array}{l}26.90 \mathrm{D}^{\prime} \\
28.09 \mathrm{C}^{\prime} \\
29.54 \mathrm{~B}^{\prime} \\
32.10 \mathrm{~A}^{\prime}\end{array}$ & $\begin{array}{l}34.14 \mathrm{D}^{\prime} \\
35.81 \mathrm{C}^{\prime} \\
37.30 \mathrm{~B}^{\prime} \\
39.87 \mathrm{~A}^{\prime}\end{array}$ & $\begin{array}{l}2007.56 \mathrm{D}^{\prime} \\
2105.88 \mathrm{C}^{\prime} \\
2193.36 \mathrm{~B}^{\prime} \\
2344.11 \mathrm{~A}^{\prime}\end{array}$ \\
\hline $\begin{array}{l}\text { Mean } \\
\text { SWE }\end{array}$ & $\begin{array}{l}0 \\
1 \\
2 \\
4\end{array}$ & $\begin{array}{l}26.53 \mathrm{D} \\
28.02 \mathrm{C} \\
30.60 \mathrm{~B} \\
31.49 \mathrm{~A}\end{array}$ & $\begin{array}{l}32.81 \mathrm{D} \\
34.86 \mathrm{C} \\
39.45 \mathrm{~B} \\
40.00 \mathrm{~A} \\
\end{array}$ & $\begin{array}{l}1929.45 \mathrm{D} \\
2049.74 \mathrm{C} \\
2319.80 \mathrm{~B} \\
2351.92 \mathrm{~A}\end{array}$ \\
\hline Control & $\begin{array}{l}0 \\
1 \\
2 \\
4\end{array}$ & $\begin{array}{l}24.70 \mathrm{k} \\
26.34 \mathrm{ij} \\
27.94 \mathrm{~h} \\
28.64 \mathrm{fh}\end{array}$ & $\begin{array}{l}31.24 \mathrm{j} \\
32.00 \mathrm{j} \\
36.99 \mathrm{fg} \\
36.33 \mathrm{~g}\end{array}$ & $\begin{array}{l}1837.20 \mathrm{j} \\
1881.61 \mathrm{j} \\
2175.18 \mathrm{fg} \\
2136.23 \mathrm{~g}\end{array}$ \\
\hline $\mathbf{R}$ & $\begin{array}{l}0 \\
1 \\
2 \\
4\end{array}$ & $\begin{array}{l}25.66 \mathrm{jk} \\
27.36 \mathrm{hi} \\
29.63 \mathrm{eg} \\
29.73 \mathrm{df}\end{array}$ & $\begin{array}{c}32.04 \mathrm{j} \\
34.70 \mathrm{~h} \\
37.97 \mathrm{ef} \\
38.55 \mathrm{de}\end{array}$ & $\begin{array}{c}1884.10 \mathrm{j} \\
2040.29 \mathrm{~h} \\
2232.46 \mathrm{ef} \\
2266.66 \mathrm{de}\end{array}$ \\
\hline MF & $\begin{array}{l}0 \\
1 \\
2 \\
4\end{array}$ & $\begin{array}{l}27.54 \mathrm{hi} \\
28.23 \mathrm{gh} \\
31.10 \mathrm{~cd} \\
31.31 \mathrm{c}\end{array}$ & $\begin{array}{c}33.32 \mathrm{i} \\
35.84 \mathrm{~g} \\
39.62 \mathrm{~cd} \\
40.44 \mathrm{c}\end{array}$ & $\begin{array}{c}1958.94 \mathrm{I} \\
2107.27 \mathrm{~g} \\
2329.48 \mathrm{~cd} \\
2377.76 \mathrm{c}\end{array}$ \\
\hline $\begin{array}{l}\mathbf{R} \\
+\end{array}$ & $\begin{array}{l}0 \\
1\end{array}$ & $28.23 \mathrm{gh}$ & $34.65 \mathrm{~h}$ & $2037.56 \mathrm{~h}$ \\
\hline MF & $\begin{array}{l}2 \\
4 \\
\end{array}$ & $\begin{array}{l}33.75 \mathrm{~b} \\
36.28 \mathrm{a}\end{array}$ & $\begin{array}{l}43.23 \mathrm{~b} \\
44.68 \mathrm{a}\end{array}$ & $\begin{array}{l}2542.08 \mathrm{~b} \\
2627.03 \mathrm{a}\end{array}$ \\
\hline L.S.D 0.05 & $\begin{array}{c}\text { Bio. } \\
\text { SWE } \\
\text { Bio* SWE }\end{array}$ & $\begin{array}{l}0.596 \\
0.476 \\
1.347\end{array}$ & $\begin{array}{c}0.56 \\
0.458 \\
1.121\end{array}$ & $\begin{array}{l}32.960 \\
26.925 \\
65.921\end{array}$ \\
\hline
\end{tabular}

Means having the same letters (s) are not significantly different. Duncan's multiple range test at $(P \leq 0.05)$

protein (\%), total carbohydrates (g/100g d.wt), P (\%) and $\mathrm{N}(\%)$ as compared with the other studied Bio treatments. These results in harmony with, Kucey (1987), Ibijbijen et al (1996), Abdel-Fattah et al (2011), Najjar et al (2012), et al (2012), Abd-Alla et al (2014) and Gamal et al (2016).

Respecting of foliar application of SWE, the obtained data showed that the foliar application of SWE (two and four $\mathrm{g}$ ) increased total protein (\%), total carbohydrates (g/100g d.wt), P (\%) and N (\%) as compared with the other studied SWE treatments. Similar effect obtained by Boghdady (2016), Abou El-Yazied et al (2012), Abo-Sedera et al (2016) and Abbas (2013).
Concerning of interactions, the studied combination between Bio and SWE indicated that plants Bio $(R+M F)$ and SWE (two and four $g$ ) showed the highest total protein (\%) and $\mathrm{N}(\%)$ than the other combination treatments. And indicated that plants Bio $(R+M F)$ and SWE (two g) showed the highest total carbohydrates $(\mathrm{g} / 100 \mathrm{~g} \mathrm{~d} . \mathrm{wt})$ and $\mathrm{P}(\%)$ than the other combination treatments.

These results can be attributed to the beneficial effect of SWE that contain naturally occurring nutrients, plant growth hormones (oxin, cytokines, and gibberelins) and other biomimulators (amino acids, and vitamins) that can maintain photosynthesis rates, improve Plant resistance, plant aging delay 
Table 4. Effect of biofertilizer (Bio.), SWE and their interaction on chemical analyses of common bean, (combined of 2016 and 2017 seasons)

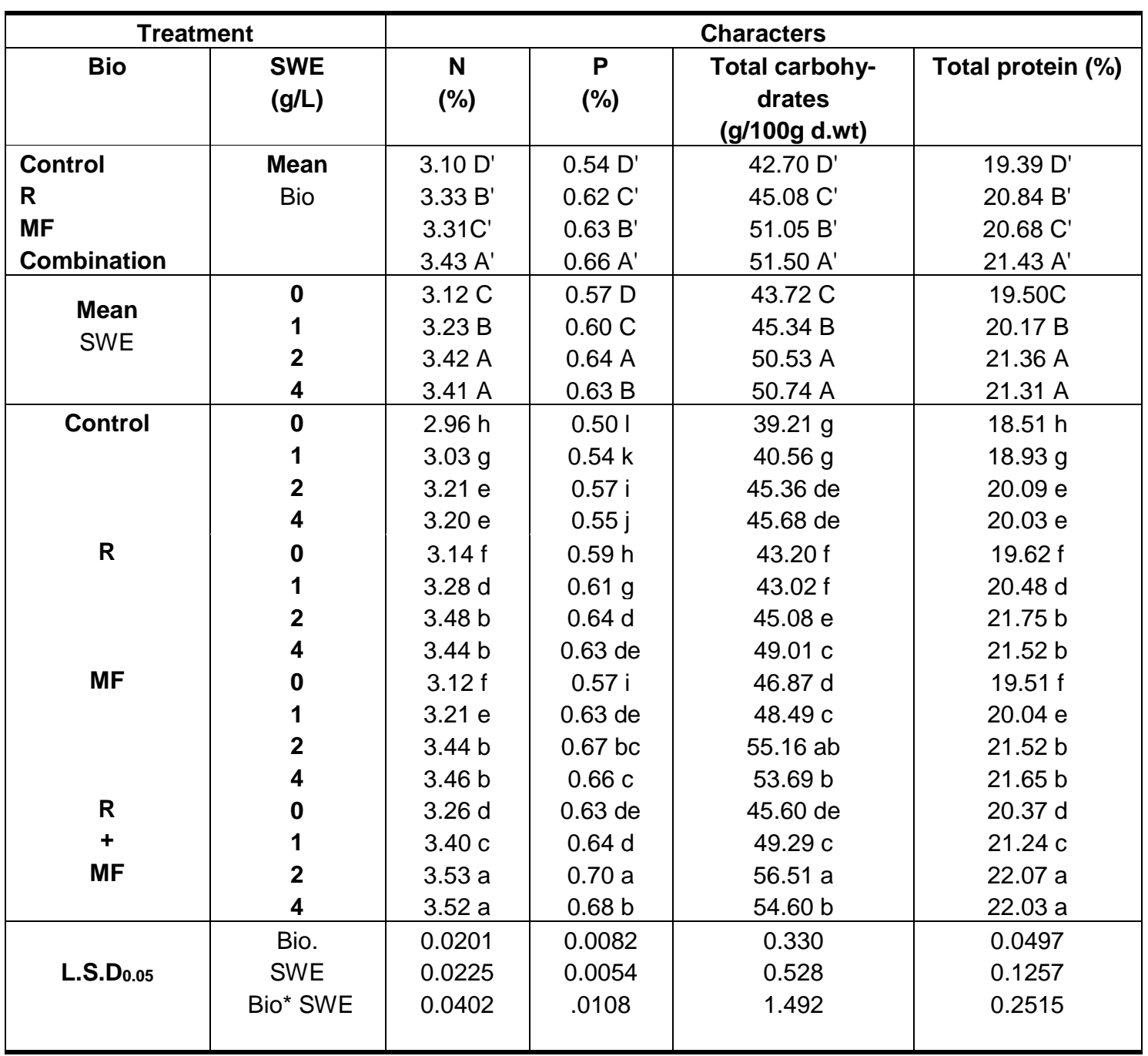

Means having the same letters (s) are not significantly different. Duncan's multiple range test at $(P \leq 0.05)$.

and control cell division. These results strongly suggest that cytokines are a biologically active ingredient in seaweed concentration. Phosphate has a profound effect on plant metabolism, growth and its economy in nature was important. MF plants are more efficient at absorbing phosphates and in legumes plants; phosphate stimulates nodule production and therefore the rate of fixation of atmospheric nitrogen is increased and Biostimulants SWE can improve plant growth may be because of:

1) Activate root cells and also stimulate biosynthesis of endogenous cytokinins from roots (Schmidt 2005).
2) Strengthen leaf water status, some plant nutrients absorption, shoot growth and root pull strength (Demir et al 2004).

3) A change hormonal balances and favors cytokinins and auxins production (Schmidt 2005).

4) Improvement of antioxidant enzymes such as (SOD, GR, ASP) for protection against adverse environmental conditions (Schmidt 2005).

5) Energizing the biosynthesis (Tocopherol, ascorbic acid and carotenoids) in chloroplast which protect photosynthetic apparatus of PSII (Zhang and Schmidt 2000). 
6) Protection of plant cells from lipid peroxidation and in activation of enzymes that occur under stress (Smirnoff 1995).

7) Energizing stem elongation and exhibits auxinlike activity.

8) Decreased uptake of $\mathrm{NaCl}$ whilst increased $\mathrm{K}$ and $\mathrm{Ca}$ content in the leaves (Demir et al 2004).

9) Energizing of chlorophyls biosynthesis (Garbay and Churin 1996) and regulation cell membrane components under drought stress (Yan 1993).

10) Prevents activity of free radical groups which are major elements for chlorophyll degradation (Fletcher et al 1988).

11) Energizing the uptake of $\mathrm{N}, \mathrm{P}, \mathrm{K}, \mathrm{Mg}, \mathrm{Ca}, \mathrm{Zn}, \mathrm{Fe}$ and $\mathrm{Cu}$ by the plants that alleviate the inhibitory effect of $\mathrm{Na}$ toxicity and restored growth.

12) Energizing of chloroplast development and enhancing phloem loading and delay senescence (Demir et al 2004).

While the development of multifunctional microbial inoculants is a promising method to increase the positive effects of microorganisms. This depends on more than one effect of the single organism or on a combination of organisms (Vassileva et al 2010). Bacterial and fungal populations can interact in the rhizosphere and stimulate plant growth and improve nutrient availability very effectively (Zaidi et al 2003; Toljander et al 2007). Additive effects between MF and plant growth-promoting bacteria were observed, e.g., after the combined application of MF and Pseudomonas species (Gamalero et al 2004) or Bacillus circulans (Singh and Kapoor, 1999).

\section{CONCLUSION}

Common bean plants obtained from seed soaked with MF, inoculated with $R$ bacteria and sprayed three times with SWE gave the best results for the quantity of the crop and the quality of seeds.

\section{REFERENCES}

A.O.A.C. 2005. Official methods of analysis. $15^{\text {th }}$ ed. Association of Official Agricultural Chemists. $12^{\text {th }}$ Ed., Washengton, D.C., USA.

Abbas S.M. 2013. The influence of biostimulants on the growth and on the biochemical composition of Vicia faba cv. Giza 3 beans. Romanian Biotechnological Letters, 18(2), 8061-8068.

Abd-Alla M.H., El-Enany A.E. and Nafady N.A. 2014. Synergistic interaction of Rhizobium legu- minosarum bv. viciae andarbuscular mycorrhizal fungi as a plant growth promotingbiofertilizers for faba bean (Vicia faba L.) in alkaline soil. Microbiological Research 169, 49-58.

Abdel-Fattah G.M., El-Haddad S.A., Hafez E.E. and Rashadd Y.M. 2011. Induction of defense responses in common bean plants by arbuscular mycorrhizal fungi. Microbiological Research 166, 268-281.

Abdel-Mawgoud A.M.R., Tantawy A.S., Hafez M.M. and Habib H.A.M. 2010. Seaweed extract improves growth, yield and quality of different watermelon hybrids", Res. J. of Agric. and Biol. Sci., 6(2), 161-186.

Abo-Sedera F.A., Shams A.S., Mohamed M.H.M. and Hamoda A.H.M. 2016. Effect of organic fertilizer and foliar spray with some safety compounds on growth and productivity of snap bean. Annals of Agric. Sci., Moshtohor., 54(1), 105118.

Abou El-Yazied, A., El-Gizawy A.M., Ragab M.I. and Hamed E.S. 2012. Effect of seaweed extract and compost treatments on growth, yield and quality of snap bean". J. of Am. Sci., 8(6), 1-20.

Boghdady M.S., Selim D.A.H., Nassar R.M.A. and Salama A.M. 2016. Influence of foliar spray with seaweed extract on growth, yield and its quality, profile of protein pattern and anatomical structure of chickpea plant (Cicer arietinum L.). Middle East J. Appl. Sci., 6(1), 207-221.

Dall'Agnol R.F., Ribeiro R.A., Delamuta J.R.M., Ormeño-Orrillo E., Rogel M.A., Andrade D.S., Martínez-Romero E. and Hungria M. 2014. Rhizobium paranaense sp. nov., an effective N2-fixing symbiont of common bean (Phaseolus vulgaris $L$.) with broad geographical distribution in Brazil. Int. J. Syst. Evol. Microbiol., 64, 3222-3229.

Demir D., Günes A., Inal A. and Alpaslan M. 2004. Effects of humic acidson the yield and mineral nutrition of cucumber (cucumis sativus I.) grown with different salinity levels. Horticulturae 492 p.

Fletcher R.A., Hofstra G. and Gao J. 1988. Comparative fungitoxic and plant growth regulating properties of triazole derivatives. Plant Cell Physiology 27, 367- 371.

Gamal M.A., Shukry A.M., Shokr M.M.B. and Ahmed M.A. 2016. Application of mycorrhizal technology for improving yield production of common bean plants. Int. J. Appl. Sci. Biotechnol, 4(2), 191-197. 
Gamalero E., Trotta A., Massa N., Copetta A., Martinotti A.G. and Berta G. 2004. Impact of two fluorescent pseudomonads and an arbuscular mycorrhizal fungus on tomato plant growth, root architecture and $\mathrm{P}$ acquisition. Mycorrhizal 14(3), 185-192.

Ibijbijen J., Urquiaga S., Ismaili M., Alves B.J.R. and Boddey R.M. 1996. Effect of arbuscular mycorrhizal fungi on growth, mineral nutrition and nitrogen fixation of three varieties of common beans \{Phaseolus vulgaris), New Phytol.134, 353-360.

Jackson M.L. 1973. Soil chemical analysis. Prentice-Hall, Inc., India. PVT. Ltd., New Delhi, 4985 p.

Kucey R.M.N. 1987. Increased Phosphorus Uptake by Wheat and Field Beans Inoculatedwith a Phosphorus Solubilizing Penicillium bilaji Strain and with Vesicular Arbuscular Mycorrhizal Fungi. Applied and Environmental Microbiology. pp. 2699-2703.

Mathur N. and Vyas A. 2000. Influence of arbuscular mycorrhizale on biomass production, nutrient uptake and physiological changes in Ziziphus mauritiana Lam. under water stress. J. Arid Envir., 45(3), 191-195.

Najjar G., Godlinski F., Vassilev N., Eichler-Löbermann B. 2012. Dual inoculation with Pseudomonas fluorescens and arbuscular mycorrhizal fungi increases phosphorus uptake of maize and faba bean from rock phosphate. Landbauforschung - vTI Agriculture and Forestry Research 3(62), 77-82.

Ramya S.S., Nagaraj S. and Vijayanand N. 2010. Biofertilizing efficiency of brown and green algae on growth, biochemichal and yield parameters of Cyamopsis (L.) Taub. Recent Research in Science and Technology, 2(5), 45-52.

Salih, S.H., Hamd S.A.M. and Dagash Y.M.I. 2015. The Effects of Rhizobium, Mycorrhizal Inoculations and Diammonium Phosphate (DAP) on Nodulation, Growth, and Yield of Soybean. Universal J. of Agric. Res., 3(1), 11-14.

Schmidt R.E. 2005. biostimulants function in turfgrass nutrition. phdemeritus virginia tech.

Shokri S. and Maadi B. 2009. Effects of arbuscular mycorrhizal fungus on the mineral nutrition and yield of Trifolium alexandrinum plants under salinity stress. J. of Agronomy 8(2), 79-83.

Singh S. and Kapoor K.K. 1999. Inoculation with phosphate solubilizing microorganisms and a vesicular arbuscular mycorrhizal fungus improves dry matter yield and nutrient uptake by wheat grown in a sandy soil. Biol. Fertil. Soils 28(2), 139-144.
Smirnoff N. 1995. Antioxidant systems and plant response to the environment. In: Environment and plant metabolism: Smirnoff N. (Ed.), Flexibility and acclimation. Oxford, UK: BIOS Scientific Publishers Ltd. pp. 217-243.

Snedecor G.W. and Cochran W.G. 1982. Statistical methods. $7^{\text {th }}$ ed. lowa state Univ., press, lowa, U.S.A.

Sridhar S. and Rengasamy R. 2010. Effect of Seaweed Liquid Fertilizer on the Growth, Biochemical Constituents and Yield of Tagetes Erecta, Under Field Trial. J. of Phytology 2(6), 61-68.

Tajini, F., Trabelsi M. and Drevon J.J. 2012. Combined inoculation with Glomus intraradices and Rhizobium tropici CIAT899 increases phosphorus use efficiency for symbiotic nitrogen fixation in common bean (Phaseolus vulgaris L.). Saudi J. of Biological Sciences 19, 157-163.

Toljander J.F., Lindahl B.D., Paul L.R., Elfstrand M. and Finlay R.D. 2007. Influence of arbuscular mycorrhizal mycelial exudates on soil bacterial growth and community structure. FEMS Microbiol Ecol 61, 295-304.

Turk M.A., Assaf T.A., Hameed K.M. and Tawaha A.M. 2006. Significance of mycorrhizale. World J. Agric. Sci. 2(1), 16-20.

Vassileva M., Serrano M., Bravo V., Jurado E., Nikolaeva I., Martos V. and Vassilev N. 2010. Multifunctional properties of phosphate-solubilizing microorganisms grown on agro-industrial wastes in fermentation and soil conditions. Appl. Microbiol. Biotechnol. 1287, 85-99.

Zaidi A., Khan M.S. and Amil M. 2003. Interactive effect of rhizotrophic microorganisms on yield and nutrient uptake of chickpea (Cicer arietinum L.). Eur J. Agron 19(1), 15-21.

Zewail R.M.Y. 2014. Effect of seaweed extract and amino acids on growth and productivity and some bioconstituents of common bean (Phaseolus vulgaris $L$ ) plants. J. Plant Production, Mansoura Univ., Mansoura, Egypt, 5(8), 1441-1453,

Zhang X. and Schmidt R.E. 2000. Hormone-containing products' impact on antioxidant status of tall fescue and creeping bentgrass subjected to drought. Crop Sci., 40, 1344-1349.

Zodape S.T., Mukhopadhyay S., Eswaran K., Reddy M.P. and Chikara J. 2010. Enhanced yield and nutritional quality in green gram (Phaseoulus radiata $\mathrm{L}$ ) treated with seaweed (kappaphycus alvarezii) extract. J. of Scientific \& Industrial Research 69, 468-471. 


\section{تأثير مستخلصات الأعثاب البحرية والأسمدة الحيوية على الإنتاج العضوي لبذور الفاصوليا}

محمود شحات أمين" - محمد زكي الثناوي - ممدوح محمد فوزي عبدالله - هاني جمال عبدالجواد قسم البساتين - كلية الزراعة - جامعة عين شمس - ص.ب 68 - حدائق شبرا 11241 - القاهرة - مصر

*Corresponding author: Shahat894@yahoo.com

Received 9 April, 2020

Accepted 7 May, 2020

أربعة مكررات، حيث كانت معاملات الأسمدة الحيوية

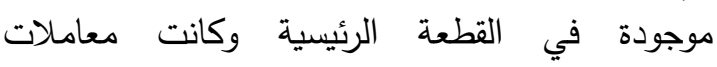

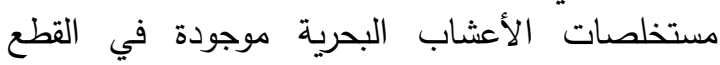

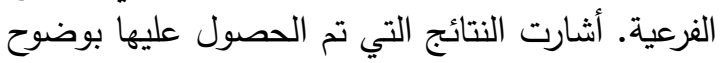

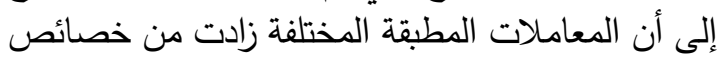

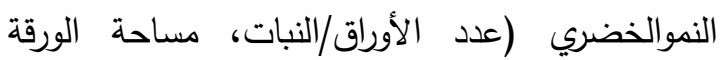

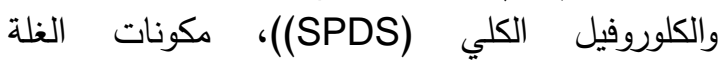

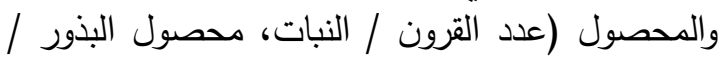
محصول النبات والبذور ) والمكونات الكيميائية (البروتين البندي

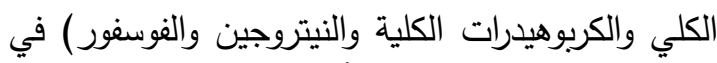

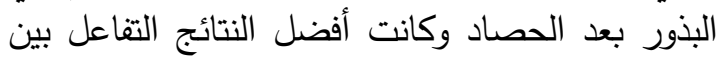

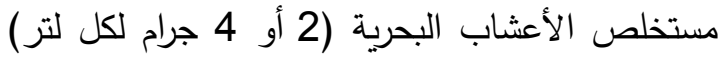
والأسمدة الحيوية (Rhizobium + Mycorrhiza) في

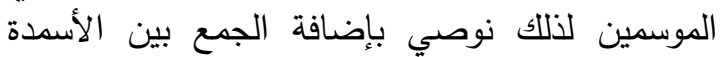
الحيوية (Rhizobium + Mycorrhiza) والأعشاب الأبن البحرية (2 أو 4 جم) لتحسين النمو الخضري والإنتاجية

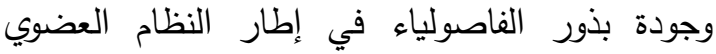
(التحول إلى الزراعة العضوية).

الكلمات المفتاحية: الأعشاب البحرية، إنتاج بذور، العيات

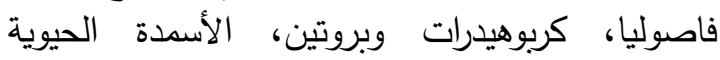
(ميكروهيزا - رايزوبياه)<smiles>[AlH2][AlH2]</smiles>

في هذه الدراسة، تم إجراء تجربتين ميدانيتين خلال

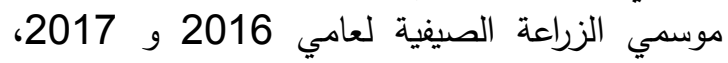
بالمزرعة التجريبية، لكلية الزراعة، جامعة الزية عين شمس، محافظة القليوبية، مصر، التجبة، من أجل التحقق في تأثير

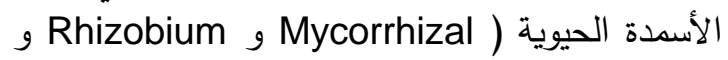
) ومستخلصات (Rhizobium + Mycorrhizal الأعشاب البحرية بتركيزات (صفر ، واحد، اثثان وأربعة

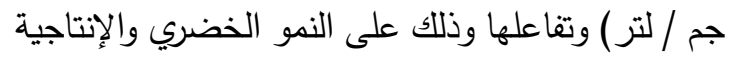

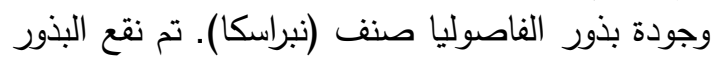

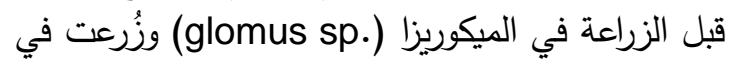
1 مارس 2016 و 2017 على التوالي. كانت مساحة القطعة التجربيية سبعة أمتار مربعة تتكون من أربعة صفوف؛ طول كل صف 2.5 متر وعرض التبار 0.7 متر . كانت المسافة بين النباتات في الصف سبع سبعة سنتيمترات على جانب واحد وتركت مسافه (عرضده متر واحد)

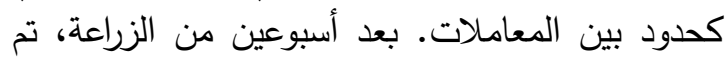
تلقيح النبات الصغير بال Rhizobium phaseolus بعد الري الأول. تم رش النبات بالت النات ثلاث مرات من

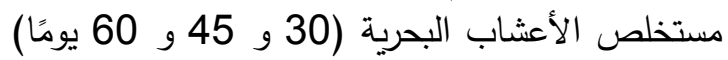
بعد الزراعة. تم استخدام تصميم قطعة الأرض المنشقة

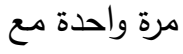

